\title{
In the Land of Pain
}

\author{
Asnia Latif, ${ }^{1}$ M. Faisal Amir Malik, ${ }^{2}$ Ali Madeeh Hashmi ${ }^{3}$
}

(Authors' Note: Alphonse Daudet (1840-1897) was a nineteenth century French novelist. A contemporary of Gustave Flaubert, Edmond de Goncourt and Emile Zola, among others, he achieved much fame and renown in his life - time. He contracted syphilis sometimes in his twenties. In the last ten years of his life, he suffered from the effects of neurosyphilis. "In the Land of Pain" is a personal account of his struggle with the illness which eventually took his life).

In the early nineteenth century, the tertiary form of syphilis began to be recognized. After lurking in the victim's blood for several years, syphilis attacked the central nervous system. The resulting condition, called neuro-syphilis, was invariably fatal. It usually manifested in two major forms: Locomotor ataxia (also called tabesdorsalis) or general paresis (also called general paresis of the insane).

Indeed, neuro-syphilis spread so widely through Europe in the nineteenth century that it came to be known as the 'disease of the century'. ${ }^{1}$ Public reaction to the disease was complicated. It did not inspire the same level of censure as the other sexually transmitted diseases of the time. ${ }^{2}$

Neuro-syphilis also made its appearance among the literary luminaries of the period. Gustav Flaubert, Charles Baudelaire, and Guy de Maupassant formed the 'big three' of the literary syphilitics. The others

\footnotetext{
${ }^{1}$ House Officer, Department of Psychiatry and Behavioral Sciences, King Edward Medical University/Mayo

Hospital, Lahore - Pakistan

${ }^{2}$ House Officer, Department of Psychiatry and Behavioral Sciences, King Edward Medical University/Mayo Hospital, Lahore - Pakistan

${ }^{3}$ Associate Professor of Psychiatry, King Edward Medical University / Mayo Hospital, Lahore, Pakistan
}

Conflict of Interest: None

Funding Source: None included Alphonse Daudet and his "doppelgänger" in pain, the Italian poet Leopardi. To illustrate the attitudes of the time towards the illness, when Maupassant contracted syphilis, this prophet of pessimism cried out in exultation: "I've got the pox! At last! Not the contemptible clap... no, no, the great pox... The majestic pox... and I'm proud of." 3 He died in 1893 after spending eighteen months in a lunatic asylum. ${ }^{3}$

When Alphonse Daudet became afflicted with neuro-syphilis, this 'happy little novelist' started to chronicle his experiences through the course of the disease. These notes were initially compiled and published as "La Dolou" ("The Pain") in 1930.

In 2002, Julian Barnes translated these notes and published them with the title, "In the Land of Pain," with a comprehensive introduction. Copious foot notes provide invaluable - and at times, witty -background to the notes. In the notes, Daudet gropes to come up with some appropriate metaphor, 'some ... term to describe the crisis ${ }^{3}$ in which he found himself. The description begins with a literary flourish: The urinary symptoms, the "nothing which was the start of everything. The invasion'. ${ }^{3}$ Soon, light reflected from windows begins to trigger excruciating pain, and after sleepless nights he hears spiders spinning their webs. His chest feels compressed, as if by a metal breastplate. As ataxia progresses, he loses control of his legs and has difficulty writing.

"Armor is exactly what it feels like, a hoop of steel cruelly crushing my back. Hot coals, stabs of pain as sharp as needles". ${ }^{3}$ In a profusion of inspired metaphors we read of pain being compared to a singer's voice, stabbing like 'wasps', feeling like the crucifixion and becoming the cruel guest and the 'impish little bird.' ${ }^{3}$ The generous use of metaphors serves, occasionally, to mitigate the grimness and dread associated with pain, disease and death. The sordid reality of experience comes through more vividly in raw, unvarnished descriptions, as when he breaks down and confesses the 'sheer dread' - of pain, death, and lone- 
liness - that he felt. Expressions of sadness turn into frank declarations of despair. 'My friends,' he writes, 'the ship is sinking. I'm going down, holed below the water - line. ... Beginning of the end' ${ }^{3}$ But amazingly, throughout it all, Daudet maintains his, at times, grim sense of humor, likening, for instance, the pangs and variety of pain, ironically, to the playing of musical instruments which make him a 'one man band of pain. $^{3,4}$

It was only in 1905 that the causative agent of syphilis, Treponema Pallidum, was discovered. And it was not until the 1940's that syphilis could be completely cured by using penicillin. ${ }^{1}$ Before that, physicians gave free rein to their ingenuity and imagination in their ultimately futile attempts to fight this tenacious illness. In the "heroic age of medicine" this meant cures which ranged from the comical to the truly tortuous.

Alphonse Daudet was friend with, and sought the advice of, some of the most celebrated physicians of the day - J. M. Charcot, Potain, Felix Guyon, Charles Edward Brown - Sequard. ${ }^{3}$ He was willing to be subjected to all sorts of treatments. These ranged from anodyne; being sent away to various spas or soaked in baths, to 'esoteric diets ... to [which] death was preferable,' to downright bizarre therapies like being injected with elixirs extracted from guinea pigs, and the extremely painful "Seyre's suspension", ostensibly employed to relieve ataxia. The various drugs of the time used included chloral, bromide, laudanum, morphine, and mercury. Mercury was widely used for syphilis in the nineteenth century, giving rise to the joke - "spending one night with Venus and the rest of your life with Mercury". At most these drugs brought temporary relief. Most of the time they caused more pain than they cured.

Interspersed in the footnotes of the book are brief, extremely insightful descriptions of famous medical or literary figures of the day e.g. this one about the 'father of Neurology', Jean - Martin (JM) Charcot (1825 1893): "For Leon Daudet, Charcot was a diagnostician and observer of genius, a man of vast erudition and 'implacable wisdom', whose case summaries were as concentrated as an Ingres ${ }^{1}$ drawing; he was without leniency towards humanity (though full of pity for animals), found the illness more interesting than the patient, and 'observed the malfunctionings of the

\footnotetext{
${ }^{1}$ The name comes from Jean - Auguste - Dominique Ingres, the eighteenth century French Neoclassical painter famous for his portraits, both painted and drawn.
}

human machine as an astronomer observes the movement of the stars'. ${ }^{3}$

Daudet finally turned to morphine for his excruciating pain. While it brought some much needed respite from pain, it was at the cost of a slew of other problems which included confusion, disorientation, a clouding of the mind and "spiteful fits". Eventually he became an addict. None of these treatments cured him. Daudet died in $1897 .^{3}$

A large number of people live with chronic pain and they are usually our least favorite patients. Living in pain is often not even considered living but only a phase to be endured, even terminated. This is not to dismiss the extremely unpleasant reality of this experience, but to counter our narrowly monolithic and instinctively adversarial attitude to pain. If pain sometimes dissolves the emotion of being it may also induce a greater awareness of self.

'Pain is not only an inevitable component of human existence but thoroughly entangled with our experiences of love, joy, humor, and intimacy. ${ }^{5}$

Most physicians have a reflexive tendency to dismiss the insights of these experiences and view them as an aberration. Worse still, often times, we casually discount these insights as yet another manifestation of pathology.

It is the very blankness of pain - the lack of anything it's truly like or about that cries out for metaphor the way a blank chalkboard invites scribbling.' Daudet struggled to convey his experience with pain, 'Are words actually any use to describe what pain (or passion for that matter) really feels like? Words only come when everything is over, when things have calmed down. They refer only to memory and are either powerless or untruthful. ${ }^{3}$ Pain is 'language destroying. ${ }^{6}$

Which suggests the mystery: Why would Daudet, then, continue to sweat on these notes for several years?

Perhaps he found the act of writing to be cathartic, even therapeutic? Perhaps he believed, as many have done through the ages, that 'suffering is instructive', and that there is a value in truths "revealed" by pain? Or maybe he held on to the hope of an eventual cure and respite from pain when he would be finally able to transform these fragmentary notes into a book.

Daudet died in 1897, his 'pain diary' incomplete. He had, apparently, stopped taking notes about three years before his death but, according to accounts of his family and friends, he maintained his zest for living till the end. His advice to his fellow pain sufferers was 
always the same: that illness should be treated as an unwanted guest to whom no special attention is accorded; daily life should continue as normally as possible. 'I don't believe I will get better' he said, 'nor does Charcot. Yet, I always behave as if my damned pains were going to disappear by tomorrow morning'.

We would do our patients a valuable service if we gave them the same advice.

\section{Conflict of Interest Notification Page}

This is to certify that authors have seen and approved the manuscript being submitted. On behalf of coauthors, the corresponding author warrants that this article has not received prior publication elsewhere. I attest to the fact that all authors listed on the title page have contributed significantly to the work, have read the manuscript and agree to its submission to the Annals of King Edward Medical University.

\section{References}

1. Shorter E. A History of Psychiatry : From the Era of the Asylum to the Age of Prozac New York: John Wiley and Sons, Inc.; 1997: 38-42.

2. Edmund C. Tramont SSB. Learning from History: What the Public Health Response to Syphilis Teaches us about HIV/AIDS. Journal of Contemporary Health Law and Policy, 2010; 26 (2): p. 253-299.

3. Daudet A. In The Land of Pain Barnes J, editor. New York: Alfred A. Knopf; 2002.

4. Sebastian Dieguez JB. The One - Man Band of Pain; Alphonse Daudet and His Painful Experience of Tabes dorsalis. Frontiers of Neurology and Neuroscience, 2005; 19: p. 17-45.

5. Mintz SB. Hurt and Pain; Literature and the Suffering Body London: Bloomsbury Publishing Plc, 2013: 242260.

6. Thernstrom M. The Pain Chronicles: Cures, Myths, Mysteries, Prayers, Diaries, Brain Scans, Healing, and the Science of Suffering New York: Farrar, Strauss and Giroux, 2010: 311-18. 